Ethiopian Journal of Environmental Studies \& Management 8(2): 152 - 160, 2015.

ISSN:1998-0507

doi: http://dx.doi.org/10.4314/ejesm.v8i2.5

Submitted: November 12, 2014

Accepted: February 17, 2015

\title{
DETERMINANTS OF FARM PRODUCTIVITY AMONG FLUTED PUMPKIN (Telfairia occidentalis Hook. F) FARMERS IN IKENNE LOCAL GOVERNMENT AREA, OGUN STATE, NIGERIA
}

\author{
BALOGUN, O.L., BELLO, T.A. and AFODU, 0.J. \\ Address: Department of Agricultural Economics \& Extension, Babcock University, Ilishan- \\ Remo, Ogun state, Nigeria
}

\begin{abstract}
Telfairia is widely cultivated for its palatable and nutritious leaves which are used mainly as vegetable. This study examined determinants of farm productivity among fluted pumpkin farmers in Ikenne Local Government Area, Ogun state, Nigeria. Two-stage sampling method was employed for this study. Data was analysed using Descriptive statistics, Total factor productivity and Ordinary least squares regression analysis. Results showed that mean age of farmer and farming experience were $40.1 \pm 1$.1years and $6.5 \pm 2.3$ years respectively. The regression result showed that cost of labour used, educational status, cost of fertilizer used, frequency of extension visits and farmers' experience siginificantly affected pumpkin farmers productivity. The study recommends the enhancement of farmers' access to education and the encouragement of the use of fertilizer and labour saving technologies in the fluted pumpkin farms.
\end{abstract}

Key Words: Farm productivity, Two-stage sampling, Access, Fluted pumpkin

\section{Introduction}

Agriculture has continues to be a primary instrument for sustainable development, poverty reduction, attainment of household self food sufficiency and food security in most developing countries in Africa (Nigeria inclusive) (Olwande et al., 2009). Despite its reputation as petroleum resource-dependent, Nigeria is predominantly an agrarian society, as a reasonable percentage of the population engages in agricultural production though at subsistence level. The sector contributed an estimated $38.6 \%$ to \% of Gross Domestic Product (GDP) to the nation's economy in 2013 with about $70 \%$ of the population productively engaged in farming (NBS, 2014). It contribution to the Gross Domestic Product has remained stable at

*Corresponding Author: Balogun, O.L.

Email: bunmi2011@yahoo.com between 30 and 42 percent, and employs 65 percent of the labour force in Nigeria (Aigbokhan, 2001). In Nigeria, more than 60 percent of the population is engaged in agricultural production; most of which are engaged in small scale production (Olutawosin and Olaniyan, 2001). Vegetable production has been inconsistent in Nigeria; for instance in 2005 about 4924.9 thousand tonnes were produced, while 2487.7 thousand tonnes were produced in $2006(\mathrm{CBN}, 2006$, Akpan et al., 2012). Vegetables are good sources of protein, mineral salts, sugars, vitamins, and essential oils that increase man's resistance to disease (Christian, 2007). Increased vegetable production improved food security and offer employment opportunities to many rural women in 
Nigeria (Francisca et al., 2006). According to Kebede and Gan (1999), the main sources of farm income for small and limited resource farmers are basically arable crop production consisting of vegetable and non-vegetable crops. In 2004, Asian Vegetable Research Development Centre for Africa (AVRDC) documented that vegetables are the most affordable and accessible sources of micronutrients and its production is increasingly recognized as a catalyst for rural development and as a means of generating foreign exchange in developing countries.

The term 'vegetable' can also be used to designate the tender edible shoots, leaves, fruits and roots of plants that are eaten whole or part raw or cooked as a supplement to starchy foods and meets (Williams et al., 1991). In human nutrition, vegetables are an essential protective food containing vitamins and minerals. Any balanced diet should include vegetables and fruits for this reason. The proportion of vegetables required in a balanced diet per capita per meal is of the order of $45 \%$ of the total volume of the food.

Fluted pumpkin Telfairia occidentalis is one of the most important vegetables grown among the people in Southwestern Nigeria. Fluted pumpkin production remains entrenched in Nigerian agriculture and forms an important condiment in the national diet (Ibekwe and Adesope, 2010). Amongst the different foods, production and consumption of fluted pumpkin is very important because of their contribution to good health by providing inexpensive sources of minerals and vitamins needed to supplement people's diet which are mainly carbohydrates (Abu and Asember 2011). Fluted pumpkin is the most important and extensively cultivated food and income generating crops in many parts of Africa (Adebisi-Adelani et al., 2011).
Staple crop production is especially plagued by many input and factor market failures (Christiaensen and Demery 2010). Increasing agricultural productivity is a vital pre-requisite for rapid economic growth and development of a country. However, Hussain and Perera (2004) observed that agricultural productivity change is explained by such factor as climatic, agronomic, and socio-economic and farm management factors. The need to increase food crop production and make food sufficient is a major concern to the country. Farmers in Nigeria are not getting maximum return from the resources committed to the enterprise. Productivity is crucial for real income growth and important for improving economic wellbeing and quality of life, or at least its material aspects. Also a better understanding of productivity trends and determinants can lead to the development of public policies and private sector actions that will serve to improve productivity performance (Sharpe, 2002).

Total Factor Productivity measures the contribution of all factors of production to productivity growth. It takes into account the productivity of factors of production other than labour, capital, intermediate goods and energy (Sharpe, 2002). In this regards, it becomes pertinent to know: What is the total farm productivity and the factors influencing the farmer's productivity cultivating fluted pumpkin in the study area?

\section{Material and Methods Study Area}

The study was carried out in Ikenne Local Government Area of Ogun State. The population of inhabitants is approximately 74, 000 people (NPC, 2006). It is bounded with the East by Odogbolu, to the South by Ayepe to the North by Ilara, to the East Ilishan and West by Sagamu Local 
Government Areas (LGAs). The local government area is located along the transitional forest zone of southern Nigeria and guinea savanna. However, the rainy season is bimodal spanning from late March to early April to mid-October, and is generally favourable for farming activities. The major economic activities of the people are farming, trading, artisan and craft. Figure 1 shows the map of Ikenne local Government Area in Ogun state, Nigeria.

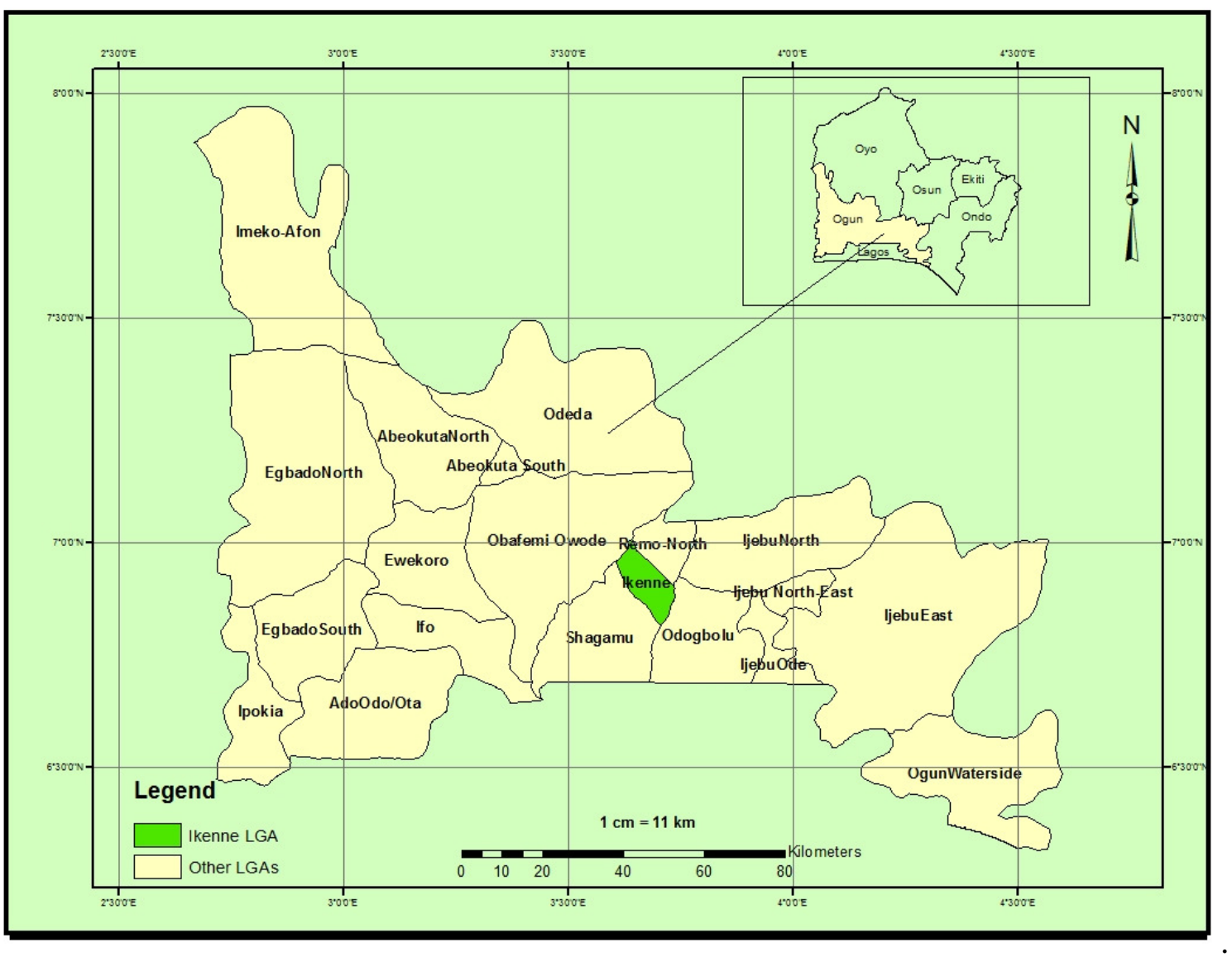

Figure 1: Map of Ogun state showing Ikenne local Government Area .

\section{Sources of Data and Sampling Procedure}

Two-stage sampling method was employed for this study using structured questionnaire. Four villages were randomly selected from the LGA. At the next selection, twenty-five pumpkin farmers were randomly selected from these villages and interviewed. In all, only eighty questionnaires that have meaningful information were used for analysis.

\section{Analytical Tools}

Descriptive statistics, Total productivity and ordinary least square regression model were used for analysis.

(i) Descriptive statistic: Descriptive statistic such as that mean, percentages, standard deviation and frequency was used to describe the socio-economic characteristics of the fluted farmers.

(ii) Total Factor Productivity (TFP): Total factor productivity was used to capture the determinants of productivity of fluted pumpkin farmers in the study area. 
Following Key and McBride (2003); Bamidele et al., (2008) and Ukoha et al., (2010), individual farm TFP can be measured as the inverse of unit variable cost. This is so since TFP is the ratio of the output to the Total Variable Cost (TVC) as shown in equation 3. This methodology ignores the role of Total Fixed Cost (TFC) as this does not affect both the profit maximization and the resource-use efficiency conditions. Besides, it is fixed and as such a constant. To determine determinants of fluted pumpkin farmer's productivity (TFP) in the study area, Ordinary Least Square regression method was applied. This methodology ignores the role of Total Fixed Cost (TFC) as this does not affect both the profit maximization and the resource-use efficiency conditions. Besides, it is fixed and as such a constant. To determine determinants of fluted pumpkin farmer's productivity (TFP) in the study area, Ordinary Least Square regression method was applied.

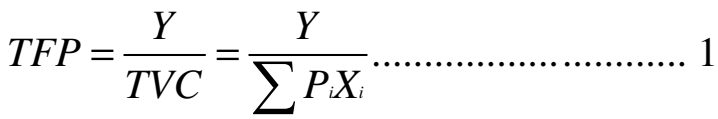

But since

$T F P=\frac{T V C}{Y}$, then

$T F P=\frac{Y}{T V C}=\frac{1}{A V C} \ldots \ldots \ldots \ldots \ldots \ldots \ldots \ldots \ldots . . .2$

$A V C=\frac{T V C}{Y}=\frac{Y}{\sum P_{i} X_{i}} \ldots \ldots \ldots \ldots \ldots \ldots \ldots \ldots \ldots . .3$

Where $\mathrm{Q}=$ quantity of output in $\mathrm{kg}$ and TVC $=$ Total Variable Cost $(\mathrm{N}), \mathrm{Pi}=$ unit price of variable input and $\mathrm{X}=$ quantity of variable input.

This is given as: $\mathrm{TFP}=\mathrm{Y}_{\mathrm{i}} / \mathrm{P}_{\mathrm{i}} \mathrm{X}_{\mathrm{i}}$

$\mathrm{TFP}=\Sigma \mathrm{Y}_{\mathrm{i}} / \Sigma \mathrm{P}_{\mathrm{i}} \mathrm{X}_{\mathrm{i}}(\mathrm{Kg} / \mathbb{N})$

Where,

TFP $=$ total factor productivity for the ith farmer

$Y_{i}=$ quantity of fluted pumpkin produced by the ith farmer
$\mathrm{P}_{\mathrm{i}}=$ unit price of the ith variable input used

$\mathrm{X}_{\mathrm{i}}=$ quantity of the ith variable input used

$\Sigma=$ summation

Ordinary Least Square regression: Ordinary Least Square regression was used to determinants of productivity of fluted pumpkin farmers. The model is specified as follows:

TFP $=$ $b_{0}+b_{1} X_{1}+b_{2} X_{2}+b_{3} X_{3}+b_{4} X_{4}+b_{5} X_{5}+b_{6} X_{6}+b_{7}$

$\mathrm{X}_{7}+\mathrm{e}_{1}$ 4

Where,

TFP = total factor productivity for the ith farmer (output value/input cost)

$\mathrm{X}_{1}=$ farm size (ha)

$X_{2}=$ cost of labour used $(\sharp)$

$\mathrm{X}_{3}=$ educational status (years)

$\mathrm{X}_{4}=$ fertilizer used ( $\mathrm{kg}$ of fertilizer)

$\mathrm{X}_{5}=$ frequency of extension visits (per season)

$\mathrm{X}_{6}=$ farming experience (years)

$\mathrm{X}_{7}=$ membership of association (Yes $=1$,

$\mathrm{No}=0$ )

$\mathrm{e}_{\mathrm{i}}=$ error term

$b_{i}=$ parameters to be estimated

$\mathrm{b}_{0}=$ intercept

\section{Results and Discussion}

Table 1 shows socio economic characteristics of the pumpkin farmers in the study area. The result shows that majority $(38.8 \%)$ of the farmers were less than 30years. The mean age of farmers in the study area was 40.1 years. This implication is that, the active labor force is involved in the cultivation of fluted pumpkin and this has a positive implication for vegetable production in study area. This is an incentive to agricultural innovation dissemination as younger farmers are more likely to adopt new technology in agricultural production (Udoh and Sunday, 2007; Akpan et al., 2010). Most (66.3\%) of the pumpkin farmers are married and the remaining are either single, divorced or seperated. Most of the farmers in the study 
area are literate with majority $(77.5 \%)$ educated more than primary school level. However, $6.2 \%$ of the pumpkin farmers had no formal education. It is well known that the level of education of farmers have significant impact on their productivity and ability to adopt new innovations and learn from what the extension agents teach them and they have the ability to combine different inputs to improve their productivity. Forty percent of the pumpkin farmers had farming experience between 710 years, while $11.3 \%, 30 \%$ and $10.8 \%$ of the pumpkin farmers had have farming experience of $0-3$ years, $4-6$ years, and above 10 years respectively. This indicates that vegetable cultivation is an emerging enterprise in the in southern Nigeria with vast potentials for increase private investment. This farming experience has enabled them to know different challenges that will affect their productivity and how to avert them before they affect their farm and also how to manage them. As farmers become more experienced in production and marketing of vegetables through their involvement, their probability to participate in economic transactions will be higher, thus becoming more productive. This result is in line with Bongiwe, 2013 findings on vegetables production in Swaziland. Furthermore, the result shows that $55 \%$ of the farmers had access to extension services with $88.8 \%$ of the them used inorganic fertilizer to produce. A few numbers of farmers used organic fertilizers as result of the poor condition of the soil used for the production of pumpkin. Hired labour were used by $76.3 \%$ of the farmers while $23.8 \%$ of the farmers relied on family labour. Majority $(73.8 \%)$ of the farmers did not have land of their own but their crops were planted on either borrowed, rented or leased land. Ownership of land influences the nature of investment that can be done on land hence; farmers who do not own land are reluctant to develop the land that is not theirs and negatively affects agriculture productivity (Randela et al., 2000).

Table 1: Socio economic characteristics of the Pumpkin farmers

\begin{tabular}{lll}
\hline & Frequency & Percentage \\
\hline Age (years) & 31 & 38.8 \\
Less than 30 & 10 & 12.5 \\
$30-40$ & 13 & 16.3 \\
$41-50$ & 22 & 27.5 \\
$51-60$ & 4 & 5.0 \\
Greater than 60 & 80 & 100.0 \\
Total & & \\
Mean= 40.1, SD=1.1 & & \\
& 53 & 66.3 \\
Marital status & 27 & 33.7 \\
Married & 80 & 100.0 \\
Otherwise & & \\
Total & 5 & 6.2 \\
& 13 & 16.3 \\
Educational status & 53 & 66.3 \\
Non formal education & 9 & 11.2 \\
Primary education & 80 & 100.0 \\
Secondary education & & \\
Tertiary education & & \\
Total & & \\
\hline
\end{tabular}




\begin{tabular}{lll} 
Farming experience (years) & & \\
$0-3$ & 6 & 11.2 \\
$4-6$ & 24 & 30.0 \\
$7-10$ & 32 & 18.0 \\
Greater than 10 & 15 & 100.0 \\
Total & 80 & \\
Mean=6.5 , SD=2.3 & & \\
Quality of extension visit & & 45.0 \\
Poor & 36 & 55.0 \\
Good & 44 & 100.0 \\
Total & 80 & \\
Types of fertilizer used & & 11.3 \\
Organic & 9 & 88.7 \\
Inorganic & 71 & 100.0 \\
Total & 80 & \\
Types of labour used & & 76.3 \\
Hired & & 23.7 \\
Family & 61 & 100.0 \\
Total & 19 & \\
Land ownership & 80 & 73.8 \\
Rented & & 26.3 \\
Owned & & 100.0 \\
Total & 59 & \\
\hline
\end{tabular}

The result of the regression analysis is presented in Table 2. The $\mathrm{R}^{2}$ values of 0.59 for fluted pumpkin farms implies that about $59 \%$ of variations in total factor productivity in fluted pumpkin enterprise is explained by the specified explanatory variables in the model. The F-ratio for the fluted pumpkin enterprise is significant at $1 \%$ which implies that the data attest to the overall significant of the regression equation. Result shows that cost of labour, educational status, cost of fertilizer used, frequency of extension visits and farming experience significantly affected productivity of pumpkin farmers. The positive relationship between cost of labour and fertilizer and farm productivity of pumpkin farmers indicates that incurring an extra cost on these inputs suggests using more of them in production. The more the labour and fertilizer put into production, the more the productivity of the farmers if the marginal physical product of these inputs is still positive. The result agrees with findings of Udoh and Akpan (2007) and Omonona and Babalola (2007) on vegetable production in the Southern Nigeria that increased input useage leads to high productivity. Education level determines the degree of opportunities available to improve living conditions. It also affects level of exposure to new ideas, managerial capacity in production, and the perception of household members on how to adopt to, and integrate, innovations (Deininger and Okidi, 2001).

The positive relationship between educational status and farm productivity is 
an indicator that farmers with higher educational status enjoy higher productivity compared to their counterparts with lower status. The positive relationship between farmers' experience in farming and farm productivity is an indicator that longer year of experience positively affects farm productivity. An additional year of experience of fluted pumpkin increased farmers productivity by $0.33 \%$. Hence, years of experience equip farmers with useful knowledge of combining inputs to maximize their output and subsequently their income.

Table 2: Ordinary Least Square Regression results for determinants of total factor productivity of fluted pumpkin farmers

\begin{tabular}{lll}
\hline Variables & coefficient & T-Statistic \\
\hline Constant & 1.487 & $3.847 * * *$ \\
Farm size & -0.202 & -0.796 \\
Cost of labour & 0.074 & $1.86^{*}$ \\
Educational status & 0.553 & $2.09^{* *}$ \\
Cost of fertilizer used & 0.147 & $1.93^{*}$ \\
Frequency of extension visit & 0.441 & $1.90^{*}$ \\
Farming experience & 0.333 & $1.67^{*}$ \\
Membership of cooperative & -0.180 & -0.60 \\
\hline$* * *$ Significant at $1 \%, * *$ Significant at $5 \%, *$ Significant at $10 \%$ & \\
$\mathrm{R}^{2}=0.59$, Adjusted $\mathrm{R}^{2}=0.57$, F-value $=1.688$ &
\end{tabular}

\section{Conclusion and Recommendation}

The study focused the determination of farm productivity among fluted pumpkin farmers in Ikenne Local Government Area, Ogun State. Telfairia farming is a major farming activity among farmers in Ikenne Local Government area. It is an enterprise with small scale resource poor farmers who heavily depend on the use of traditional technologies which results in low productivity. The study has indicated that the cost of labour, educational status, frequency with extension agent, farming experience and fertilizer used has direct significance on the total factor productivity level of the fluted pumpkin farmers. Based on the finding of this study, the following recommendations may be appropriate for increasing the farmers total factor productivity. The results therefore calls for farm level policies aimed at intensifying extension services among the farmers to help sustaining the current level of factor productivity. Also, policy that will encourage farm mechanization in vegetable production is strongly advocated so as to reduce the effect of high labour cost. In addition, compulsory universal education policies of the federal government should be strongly upheld; to enable farmers allocate their resources more efficiently.

\section{References}

Abu, O. and Asember, D.J. (2011). Opportunities for Smallholder Spinach Farmers in Nigeria: A Profit Efficiency Analysis. Journal of Economics, 2(2): 75-79

Adebisi-Adelani, O., Olajide-Taiwo, F.B., Adeoye, I.B and Olajide- Taiwo, L.O (2011). Analysis of Production Constraints facing Fadama Vegetable Farmers in Oyo State, Nigeria. World Journal of Agricultural Sciences 7(2): 189-192.

Akpan, S.B., Udoh, E.J. and Aya, E.A., (2010). Fertiliser-Manure Substation among Arable Crop Farmers in Akwa Ibom State:empirical evidence. 
Global Journal of Agricultural sciences, 9(1): 37-40.

Akpan, S.B., Udoh, U.J., Bassey, E.E., Inya-agba, C. and Udoh, F.J. (2012). Analysis of Resource Productivity and the Level of Fertilizer - Manure Substitution Among Vegetable Farmers in the Southern Region of Nigeria. Mediterranean Journal of Social Sciences, 3(2): 35-46.

Asian Vegetable Research Development Centre for Africa (AVRDC) (2004). 11th Regional Training Course on Vegetable Crop Production and Research. Tanzania 4th July - 4th November, 2004.

Bamidele, F.S., Babatunde, R.O. and Rasheed, A. (2008). Productivity Analysis of Cassava- Based Production Systems in the Guinea Savannah: Case Study of Kwara State, Nigeria. American-Eurasian Journal of Scientific Research 3(1): 33-39.

Bakhru, H.K. (2003): Foods That Heal. The Natural Way to Good Health. Orient Paperbacks, Delhi, Pp 82 - 90.

Central Bank of Nigeria. (2006). Annual Report and Statement of Accounts. Abuja.

Christian, A. (2007). Fluted Pumpkin (Telfairia occidentalis) Seed: A Nutritional Assessment. Electronic Journal of Environment, Agriculture and Food Chemistry, 6(2): 2007

Christiaensen, L. and Demery, L. (2010). Are African Countries Paying Too Much Attention To Agriculture? WIDER Working Paper 2010. http://www.wider.unu.edu/publication s/workingpapers/2010/en_GB/wp2010-36/ accessed 03-09-2011

Deininger, K. and J. Okidi. (2001). Rural households: Incomes, productivity, and nonfarm enterprises. In Uganda's recovery: the role of farms, firms, and government, eds. R. Reinikka and P. Collier. Washington, D.C.: The World Bank.

Francisca, S. I. and Eyzayuirre, P. (2006). African leafy vegetables: Their Role in the World Health Organization's Global Fruit and Vegetable Initiative

Hussain, I. and Perera L.R. (2004). Improving Agricultural Productivity through Integrated Service Provision with Public-Private Sector Partnerships. Working Paper 66. Colombo, Sri Lanka:International Water Management Institute.

Ibekwe, U.C. and Adesope, O.M. (2010). Analysis of dry season vegetable production in Owerri West Local Government Area of Imo State, Nigeria. Journal of Development and Agricultural Econonomics, 2(6): 245249 ,

Kebede, E. and Gan, J. (1999). The Economic Potential of Vegetable Production for Limited Resource Farmers in South Central Alabama. Journal of Agribusiness, 17(1): 63-75.

Key, N. and Mcbride, W. (2003). Production Contracts and Productivity in the US Hog Sector". Am. J. Agric. Econ., 85(1): 121-133

National Bureau of Statistics (NBS) (2014) Nigerian Gross Domestic Report 2014 Issue 01, National Bureau of Statistics, Abuja, Nigeria

Olutawosin G.A. and G.O. Olaniyan, (2001). Planning sustainable land management system for continuous crop production in Nigeria: An ecosystem approach: Paper presented at Ecofarming Workshop NECOFANIGERIA, Dec. 20-21 pp.17-24

Olwande, J., Geophrey, S and Mathenge, M (2009). Agricultural Technology Adoption: A Panel Analysis of Smallholder Farmers' Fertilizer use in 
Kenya. African Economic Research Consortium Conference paper

Omonona, B.T. and D. A. Babalola, (2007). Determinants of the production of Fluted

Pumpkin among Farmers in Nigeria. Journal of Agricultural and Food Information, 8(1): 95- 105 .

Randela, R., Liebenberg, C.F., Kirsten, J. F. and Townsend, R.F. (2000). Demand for livestock tick control service in the Venda region, Northern Province. Agrekon, 39(4): 644-655.

Sharpe, A. (2002). "The Contribution of Productivity to Economic WellBeing." In Productivity Issues inCanada, ed. S. Rao, and A. Sharpe. Calgary: University of Calgary Press.

Tindall, H.D (1983). Vegetables in the tropics. Macmillan Press limited, London and Basingstoke.
Udoh, E. J. and Sunday B. A., (2007) "Measuring Technical efficiency of waterleaf (Talinum triangulare) production in Akwa Ibom State, Nigeria", American-Eurasian J. Agric. Environ. Sci., 2: 518 - 522.

Ukoha, O.O., Okoye, B.C. and Emetu, J. (2010). Analysis of the Determinants of Total Factor Productivity among Small-Holder Cassava Farmers in Ohafia L.G.A of Abia State. Munich Personal RePEc Archive. MPRA Paper No. 26125.

Williams, D.A., Rios, M., Stephens, C., and Patel, V.P. (1991). Fibronectin and VLA-4 in Haematopoietic Stem CellMicroenvironment Interactions. Nature, 352: 438-441. 